\title{
Effects of Peptide-Induced Immune Tolerance on Murine Lupus
}

\author{
Ram P. Singh ${ }^{1,2^{\star x}}$, Bevra H. Hahn ${ }^{2}$ and David S. Bischoff ${ }^{1,3}$ \\ ${ }^{1}$ Research Service, Veteran Administration Greater Los Angeles Healthcare System, Los Angeles, CA, United States, \\ 2 Division of Rheumatology, Department of Medicine, University of California, Los Angeles, Los Angeles, CA, United States, \\ ${ }^{3}$ Department of Medicine, University of California, Los Angeles, Los Angeles, CA, United States
}

OPEN ACCESS

Edited by:

Ciriaco A. Piccirillo,

McGill University, Canada

Reviewed by:

Bhagirath Singh,

Western University, Canada

Fan Pan,

Chinese Academy

of Sciences (CAS), China

*Correspondence:

Ram P. Singh

ram.singh@va.gov;

rpsingh11@hotmail.com

${ }^{\dagger}$ Present address:

Ram P. Singh,

Research Service, Veteran Administration Greater Los Angeles Healthcare System, Los Angeles, CA, United States

Specialty section:

This article was submitted to Immunological Tolerance and Regulation,

a section of the journal

Frontiers in Immunology

Received: 01 February 2021 Accepted: 28 April 2021

Published: 19 May 2021

Citation:

Singh RP, Hahn BH and Bischoff DS (2021) Effects of Peptide-Induced Immune Tolerance on Murine Lupus.

Front. Immunol. 12:662901.

doi: 10.3389/fimmu.2021.662901
The regulation of autoimmunity and the molecular mechanisms by which different immune cells, including T cells, polymorphonuclear leukocytes (PMN-granulocytes), and B cells suppress autoimmune diseases is complex. We have shown previously that BWF1 lupus mice are protected from autoimmunity after i.v. injection or oral administration of tolerogenic doses of pCons, an artificial synthetic peptide based on sequences containing $\mathrm{MHC}$ class I and $\mathrm{MHC}$ class II determinants in the $\mathrm{VH}$ region of a J558encoded BWF1 anti-DNA Ab. Several T cell subsets can transfer this tolerance. In this study, we determined the potential roles of granulocytes, B cells and regulatory $T$ cells altered by pCons treatment in the BWF1 (NZB/NZW) mouse model of lupus. Immunophenotyping studies indicated that pCons treatment of BWF1 mice significantly increased $\mathrm{CD}^{+}{ }^{+} \mathrm{FoxP}^{+}{ }^{+} \mathrm{T}$ cells, reduced the percent of $\mathrm{B}$ cells expressing $\mathrm{CD} 19^{+} \mathrm{CD}^{+}$ but increased the percent of $C D 19^{+} \mathrm{CD} 1 \mathrm{~d}^{+}$regulatory $\mathrm{B}$ cells and increased the ability of the whole $B$ cell population to suppress IgG anti-DNA production in vitro. pCons treatment significantly decreased the expression of CTLA-4 (cytotoxic T-lymphocyte-associated protein-4) in $\mathrm{CD}^{+} \mathrm{T}$ cells. In addition, peptide administration modified granulocytes so they became suppressive. We co-cultured sorted naïve B cells from mice making antiDNA Ab (supported by addition of sorted naive $\mathrm{CD} 4^{+}$and $\mathrm{CD}^{+} \mathrm{T}$ cells from young autoantibody-negative BWF1 mice) with sorted B cells or granulocytes from tolerized mice. Both tolerized granulocytes and tolerized B cells significantly suppressed the production of anti-DNA in vitro. In granulocytes from tolerized mice compared to saline-treated littermate controls, real-time PCR analysis indicated that expression of interferon-induced TNFAIP2 increased more than 2-fold while Ptdss2 and GATA1 mRNA were up-regulated more than 10-fold. In contrast, expression of these genes was significantly downregulated in tolerized $\mathrm{B}$ cells. Further, another IFN-induced protein, Bcl2, was reduced in tolerized $\mathrm{B}$ cells as determined by Western blot analyses. In contrast, expression of FoxP3 was significantly increased in tolerized B cells. Together, these data suggest that B cells and granulocytes are altered toward suppressive functions by in vivo tolerization of BWF1 mice with pCons and it is possible these cell types participate in the clinical benefits seen in vivo.

Keywords: regulatory B cells, immune tolerance and regulation, pConsensus peptide (pCons), systemic lupus erythematosus, Anti-DNA Ab, polymorphonuclear cells (PMNs), granulocytes 


\section{INTRODUCTION}

Regulatory B cells and regulatory polymorphonuclear leukocytes (PMNs-granulocytes) influence immunity but are not well understood in systemic autoimmunity. Lupus causes significant morbidity, mortality, and economic loss. Systemic lupus erythematosus (SLE) is probably initiated by autoantibodies (e.g. anti-DNA) and immune complexes that induced inflammation and organ damage (1). One of the organs affected in some patients with SLE is the kidney and lupus nephritis is a leading cause of end stage kidney disease and death. Approximately two million people suffer from this disease, with the majority of cases being women of childbearing age. Lupus is a gender-biased disease with a female to male ratio of 9:1. African-American women are three times more likely to get lupus than Caucasian women. Lupus is also more common in Hispanic, Asian, and Native American women than in Caucasians. In the last 50 years, there have been only two new lupus-specific therapy approved by the FDA, Benlysta (antiBAFF, and voclosporin (a calcineurin inhibitor). Current treatments, including the newer ones, rarely induce sustained disease remission. Therefore, additional treatment strategies are urgently needed. The modulation of abnormal immune regulation is an object of intense investigation in several experimental autoimmune diseases with the goal to limit the numbers of abnormal pathogenic cells and autoantibodies, and to achieve restoration of immune system self-tolerance by the administration of peptides that induce regulatory cells.

We have focused studies in a mouse model of SLE, the BWF1New Zealand Black/New Zealand White (NZB/NZW) mouse, which has several characteristics in common with human SLE (2, 3). These mice spontaneously develop fatal immune mediated glomerulonephritis with high titers of anti-nuclear antibodies including high affinity IgG antibodies to dsDNA and show female to male bias. In this model, we used a peptide, pCons, to induce regulatory cells which are protective in SLE. We studied gene expression in splenocytes using Affymetrix microarray analysis (448 genes were differentially regulated one week after tolerance induction), followed by validation studies with quantitative real-time RT-PCR in $\mathrm{CD}^{+}$and $\mathrm{CD}^{+} \mathrm{T}$ cell subsets. In the current study, we test for potential molecular mechanisms that govern the function of tolerized $\mathrm{B}$ cells (including $\mathrm{B}_{\text {regs }}$ ) and PMNs-granulocytes in this model.

Regulatory $B$ cells $\left(\mathrm{B}_{\text {regs }}\right)$, a novel subpopulation of $B$ cells, are a significant area of research due to their therapeutic relevance, immune regulatory function, and ability to sustain self-tolerance (4-6). Evidence suggesting a role for $\left(\mathrm{B}_{\text {regs }}\right)$ in the immune system has been described since the 1970s. These studies suggest that there is a potential role for $\mathrm{B}_{\text {regs }}$ in reducing $\mathrm{T}$ cell activity and inducing immune tolerance (7-10). Over the past decade, $B_{\text {regs }}$ have been identified in many autoimmune diseases (11-17). Approaches to manipulate B cells in a manner that is beneficial in attenuating inflammatory and autoimmune conditions, including SLE, are not clear. The mechanisms by which $\mathrm{B}_{\text {regs }}$ influence the functions of $\mathrm{CD}^{+}{ }^{+}$and $\mathrm{CD} 8^{+} \mathrm{T}_{\text {regs }}$ are not known. Additionally, genes expressed in $B_{\text {reg }}$ cells (other than IL-10) that offer protective responses and their molecular mechanisms of function remain to be defined.
Polymorphonuclear neutrophils (PMN-granulocytes) have been shown to play a role in a variety of autoimmune diseases including Rheumatoid Arthritis (18), Inflammatory Bowel Disease $(19,20)$, and Experimental Autoimmune Encephalomyelitis (EAE) (21). Studies have shown that PMNs-granulocytes are capable of interacting with $\mathrm{T}$ cells by presenting class I and class II restricted antigens on their surface (22-26) as well as in a non-MHC restricted fashion (22). PMNs-granulocytes have also been shown to express the costimulatory molecules CD80 and CD86 (27), the regulation of which is important in autoimmunity and immune tolerance. In patients with SLE, granulocytes undergoing NETosis are increased, and the nets contain DNA/nucleosome/proteins that promote autoreactivity and production of type 1 IFNs (28). The exact mechanisms of PMNs-granulocytes and $B_{\text {regs }}$ interaction with other regulatory cells and their cross-talk are currently poorly defined. In this report, we provide novel evidence that $\mathrm{pCons}$ tolerance induces $\mathrm{CD}^{+}{ }^{+} \mathrm{FoxP}^{+}{ }^{+} \mathrm{T}$ cells and potent regulatory $\mathrm{B}$ cells and granulocytes capable of suppressing autoimmunity in vitro in a murine model of SLE. Understanding the role of regulatory T cells, B cells and granulocytes may provide novel mechanistic insight for SLE and expand our knowledge of immune tolerance and can identify potential new targets for SLE.

\section{MATERIALS AND METHODS}

\section{Mice}

NZB (H-2d/d), NZW (H-2z/z) and NZB/NZW F1 (H-2d/z) mice were purchased from the Jackson Laboratories (Bar Harbor, ME, USA) or bred at the University of California Los Angeles (UCLA). All mice were treated in accordance with the guidelines of the University of California Los Angeles Animal Research Committee, an Institution accredited by the Association for Assessment and Accreditation of Laboratory Animal Care (AAALAC). Mice were housed in pathogen-free conditions. Female mice were used for all experiments.

\section{Peptides}

The peptides used in this study and the MHC molecules they bind have been described earlier $(29,30)$. pCons (FIEWNKLRFRQGLEW), the artificial tolerizing peptide, contains T-cell determinants based on the J558 VH regions of several murine anti-dsDNA Ab from BWF1 mice (29, 31-35). Peptides were synthesized at Chiron Biochemicals (San Diego, CA, USA), purified to a single peak on high-performance liquid chromatography, and analyzed by mass spectroscopy for expected amino acid content.

\section{Treatment of Mice}

Ten- to twelve-week-old BWF1 mice received a single i.v. dose of $1 \mathrm{mg}$ of pCons, dissolved in saline, as reported previously $(29,31$, 36) for tolerance induction. For immunophenotyping of regulatory B cells, female 35-wk-old BWF1 mice were used and injected with pCons (1 mg i.v.). After 3 days, blood was obtained, RBC lysed, and cells were stained with CD19, CD1d and CD5 
antibodies and FACS performed. Control mice received either a similar amount of pNeg (negative control peptide) or saline.

\section{Cell Isolation, Preparation, Immunophenotyping, and Flow cytometry}

Spleen cells were isolated $\sim 1$ week after administration of the pCons peptide from tolerized, saline-treated, or naïve BWF1 mice. Single cell suspensions of splenocytes were prepared by passing cells through cell strainers (Fisher). ACK lysing buffer, (Sigma, St Louis, MO, USA) was used to lyse red blood cells. Cells were washed and re-suspended in RPMI complete media. Cell subsets were further enriched following incubation with antiCD4 (L3T4), anti-B (CD45R/B220), anti-CD8 (CD8a Ly-2), antiNK1.1 (CD95b), anti-DX5, anti-CD11C, and anti-Gr-1 microbeads from Miltenyi Biotech (Auburn, CA, USA). Purity of cells was determined to be more than $90 \%$ pure as assessed by flow cytometry (FACS). For immunophenotyping, isolated cells were washed with FACS buffer and 1-2 million cells were used for surface staining. Before staining, cells were incubated with rat anti-mouse CD16/ CD32 (FC III/II receptor) Ab to block nonspecific binding.

For regulatory B cell immunophenotyping, female 35 wk-old BWF1 mice were treated with pCons $1 \mathrm{mg}$ i.v. and blood was obtained after (3-5 days). Splenocytes were depleted of red blood cells (RBCs) and then stained with CD19, CD1d, and CD5 antibodies for FACS analysis. Antibodies for cell surface staining and isotype controls were from $\mathrm{BD}$ Biosciences, $\mathrm{BD}$ Pharmingen, eBiosciences, or BioLegend. CD4 (L3T4), CD25 (PC61.5) and CTLA-4 (UC10-4F10-11) staining was performed with antibodies from BD Pharmingen. FoxP3 (FJK-16s) staining was performed with an eBiosciences intracellular kit. Data were collected using FACSCalibur (BD Biosciences) and analyzed by BD Cell Quest software (Becton-Dickinson, Mountain View, CA) or FCS De Nova software (Thornhill, Ontario, Canada).

\section{Western Blot Analysis}

Western blot analyses were performed as described earlier (37). In brief, cell lysates were prepared from the naïve and tolerized $\mathrm{B}$ cells from the splenocytes of naive and pCons-treated BWF1 mice. Cells were lysed with RIPA buffer $(150 \mathrm{nM} \mathrm{NaCl}, 1.0 \% \mathrm{NP}-$ $40,0.5 \%$ sodium deoxycholate, $0.1 \%$ SDS, $10 \mathrm{mM}$ Tris, $\mathrm{pH} 7.3$ ) supplemented with Protease Arrest protease inhibitor cocktail solution (G Biosciences, Maryland Heights, MO, USA). Protein was measured from each sample using the Bradford assay (BioRad Laboratories, Hercules, CA, USA) and an equal amount of protein was loaded in each well. The lysates were resolved on a 4-12\% NuPage gel (Invitrogen, Carlsbad, CA, USA) in reducing conditions. Proteins were electro-transferred onto a polyvinylidene fluoride membrane (Invitrogen). The membranes were blocked with $3 \% \mathrm{BSA}$ and immunoblotted with a specific antibody, bcl2 (50E3), (1:200 dilution; Cell Signaling Technology, Inc.) or $\beta$-actin (1:100 000 dilution; Sigma, Inc.). Following washing, the membranes were incubated in secondary antibodies (1:2500 dilution; Santa Cruz Inc, Santa Cruz, CA, USA). All blocking, incubation and washing steps were performed in TBST (TBS and $0.1 \%$ Tween 20). Proteins were visualized using ECL (GE Healthcare, Buckinghamshire, UK).

\section{RNA Isolation and Real-Time PCR}

Total cellular RNA was isolated from purified cell subsets or total splenocytes from saline-treated or pCons-tolerized BWF1 mice with TRIzol (Invitrogen, Carlsbad, CA, USA) as per manufacturer's protocols. Real-time PCR was performed as described earlier (29, 33-35). Each experimental group consists of the pooled spleen cells of 3-4 mice from each group. 100 ng of total RNA was used with onestep RT-PCR reagents (Applied Biosystems, Foster City, CA, USA). Quantitative real-time reverse transcription was performed using TaqMan technology on an ABI Prism 7900 HT Sequence Detection System (Applied Biosystems). Primers and probes of IFI205, GATA1, Ptdss2, TNFip2, FoxP3 and GAPDH were obtained from Applied Biosystems, Foster City, CA, USA. The oligonucleotide sequences used for the primers and TaqMan probes (Applied Biosystem, Foster City, CA) are described $(29,33-35)$. GAPDH was used as an endogenous control in each experimental set.

\section{Cell Culture and Measurement of Anti-DNA Antibodies}

Assays were performed to measure anti-DNA $\mathrm{Ab}$ as described earlier $(29,31,34,35,37)$. For optimal Ab production, B cells $\left(1 \times 10^{5}\right.$ cells) from keep old (40-50-wk-old) naïve BWF1 females with $3+$ proteinuria or higher, $\mathrm{CD} 4^{+} \mathrm{CD} 25^{-} \mathrm{T}$ cells $\left(1 \times 10^{6}\right)$ from young 10-12-wk-old naive BWF1 females without proteinuria, naive $\mathrm{CD}^{+} \mathrm{T}$ cells $\left(1 \times 10^{6}\right)$, and irradiated APC $\left(1 \times 10^{5}\right)$ cells were isolated and cultured with granulocytes or B cells $\left(1 \times 10^{6}\right)$ from tolerized mice or controls. Cell cultures were performed in RPMI 1640 supplemented with L-glutamine $(2 \mathrm{mM})$, penicillin (100 units/ml), streptomycin $(0.1 \mathrm{mg} / \mathrm{ml}), 2$-mercaptoethanol (Gibco) and $10 \%$ fetal bovine serum (FBS). For tolerized B cells analysis, we cultured, as indicated above pCons-tolerized B cells $\left(1 \mathrm{x} 10^{6}\right)$ with naïve $\mathrm{CD} 4^{+} \mathrm{CD} 25^{-} \mathrm{T}$ cells $\left(1 \times 10^{6}\right)$, naïve $\mathrm{B}\left(1 \times 10^{5}\right)$ and/or naïve $\mathrm{CD}^{+} \mathrm{T}$ cells $\left(1 \times 10^{6}\right)$ cells. After $72-96$ hours, culture supernatants were obtained and anti-DNA IgG was measured by ELISA.

\section{Statistical Analyses}

Data were analyzed using Prism 4.0 (GraphPad Software, San Diego, CA). Comparisons were performed using paired one- or two-tailed test. Nonparametric testing among more than two groups was performed by one-way ANOVA. Results are expressed as mean \pm SEM. $\mathrm{p}<0.05$ was considered significant.

\section{RESULTS}

\section{pCons-Induced Tolerized B Cells and Granulocytes Suppressed Anti-DNA Ab Production by BWF1 Cells}

To our knowledge, no studies have been performed to address the role of regulatory $\mathrm{B}$ cells and granulocytes in the immune tolerance and BWF1 lupus. To address this, we harvested B cells and granulocytes from the spleens of naïve and tolerized BWF1 mice 7 days after the induction of tolerance (peptide treatment $1 \mathrm{mg}$ i.v. once a week). We used in vitro assays to test the effects of each cell type on anti-DNA Ab production with the addition of naïve $\mathrm{CD} 4^{+}$helper cells ( $\mathrm{CD} 4^{+} \mathrm{CD} 25^{-} \mathrm{T}$ cells) plus naïve $\mathrm{B}$ cells 
(from old BWF1 nephritic mice) and naïve $\mathrm{CD} 8^{+} \mathrm{T}$ cells to each cultured subset either separately or in combination with tolerized $\mathrm{B}$ cells $\left(\mathrm{B}_{\text {regs }}\right)$ and granulocytes. Anti-DNA Ab was analyzed as described previously $(29,31,34,35,37)$. Briefly, purified populations of different spleen effector cell subsets including $\mathrm{B}$ cells, naïve $\mathrm{CD} 4^{+} \mathrm{T}$ cells ( $\mathrm{CD} 4^{+} \mathrm{CD} 25^{-}$Tcells), naïve $\mathrm{CD} 8^{+} \mathrm{T}$ cells, and tolerized granulocytes and $\mathrm{B}$ cells were harvested (using the appropriate Miltenyi Biotec microbeads via AutoMACS) one week after pCons treatment of BWF1 mice. Naïve $\mathrm{CD}^{+}{ }^{+} \mathrm{T}$ cells from young mice (10-12-weeks-old) and B cells from old nephritic BWF1 mice (40-50-weeks-old with $3+$ proteinuria) were co-cultured in complete medium with tolerized/regulatory B cells and granulocytes and other effector cell types such as (naïve $\mathrm{CD}^{+} \mathrm{T}$ cells) from spleens of tolerized mice. Our previous cell-dose response study with $\mathrm{CD} 8^{+}$Treg showed that $1 \times 10^{6}$ cells are optimum in mixed cell culture experiments (29) therefore, we used the same number of cells in these experiments. In addition previously, we had found that a ratio of $\mathrm{B}$ cells to helper $\mathrm{T}$ cells $\left(\mathrm{CD} 4^{+} \mathrm{CD} 25^{-} \mathrm{T}\right.$ cells) to regulatory/suppressor $\mathrm{T}$ cells of 1:10:10 are needed to observe optimal suppression of anti-DNA antibodies $(29,32,35)$. Therefore, we used this same ratio with each effector cell type. We found that both tolerized B cells and granulocytes suppressed the production of anti-DNA Ab (Figures 1 and 2). Although we did not determine whether this suppressive effect was direct or indirect on autoreactive B cells through $\mathrm{CD}^{+}$or $\mathrm{CD}^{+} \mathrm{T}$ cells or by synergistic effect by those cells with tolerized $\mathrm{B}$ cells and granulocytes, this data clearly suggests that pCons-induced regulatory B cells and granulocytes suppress the anti-DNA Ab production and thus play a significant role in autoimmunity.

\section{Microarray Analysis Showed Altered Regulation of Genes in Non-T Cells}

Since our previous published microarray data showed that pCons treatment induces major changes in white blood cells (WBC) subsets of BWF1 spleen cells [448 genes differentiallyregulated in whole splenocytes of tolerized compared to control mice (33)], we were interested to see the potential role of regulatory B cells and granulocytes. Thus, in this report, we characterized expression of selected genes (highly upregulated) in different cell populations in non-T cells (tolerized B cells and tolerized granulocytes cells) and further tested the ability of these cell subsets to suppress production of anti-DNA Ab in lupus. Our data suggests that cell types other than $\mathrm{T}$ cells may play major roles in this model of immune tolerance.

\section{B cells and Granulocytes Produced Significantly Increased/Decreased Amounts of mRNA for Several Genes of Interest Including Interferon Genes After pCons Treatment in BWF1 Lupus Mice}

To address the role of tolerized non- $\mathrm{T}$ cell subsets after pCons treatment in BWF1 mice, B cells and granulocytes were obtained from the spleen of BWF1 mice 1 weeks after pCons treatment. RNA was isolated from these cell subsets and real-time PCR was performed as described earlier (33). Real-time PCR analyses

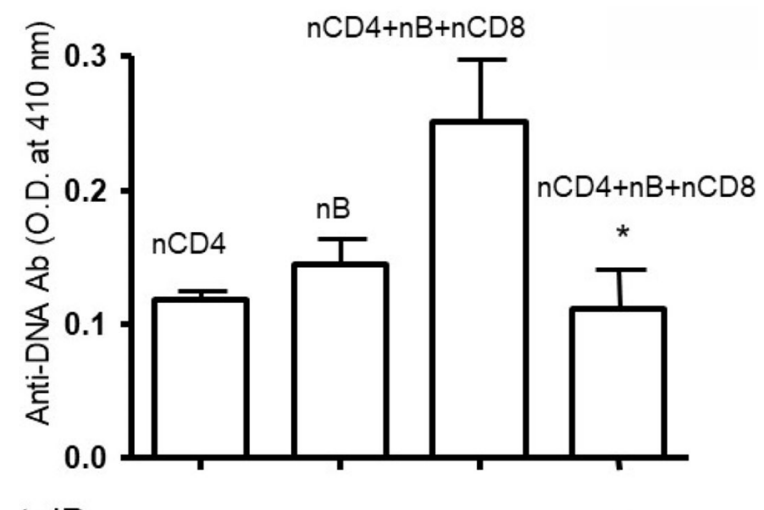

tolB

FIGURE 1 | Anti-DNA Ab was significantly decreased in the presence of tolerized B cells. Naiive $C D 4^{+} T$ cells, CD8+ $T$ cells and $C D 45 R / B 220^{+} B$ cells were isolated from BWF1 mice spleen cells using microbeads from Miltenyi Biotech (Auburn, CA, USA). Cells were cultured in RPMl 1640 supplemented with L-glutamine (2 mM), penicillin (100 units $/ \mathrm{ml})$, streptomycin $(0.1 \mathrm{mg} / \mathrm{ml})$, 2-mercaptoethanol (Gibco) and 10\% fetal bovine serum (FBS). Cells were cocultured in the presence of tolerized B cells $\left(1 \times 10^{6}\right.$ cells). Different immune cell subsets (naïve $\mathrm{B}$ cells, $1 \times 10^{5}$ cells from old nephritic mice; $\mathrm{CD}^{+} \mathrm{CD} 25^{-} \mathrm{T}$ cells, $1 \times 10^{6}$; naiive $\mathrm{CD} 8^{+} \mathrm{T}$ cells, $1 \times 10^{5}$ ) were isolated from splenocytes and cultured with tolerized $B$ cells $\left(1 \times 10^{6}\right.$ cells). After the 72-96 hours range, culture supernatants were obtained. Anti-DNA Ab levels were measured from culture supernatants by ELISA. ${ }^{*} \mathrm{p}<0.05$.

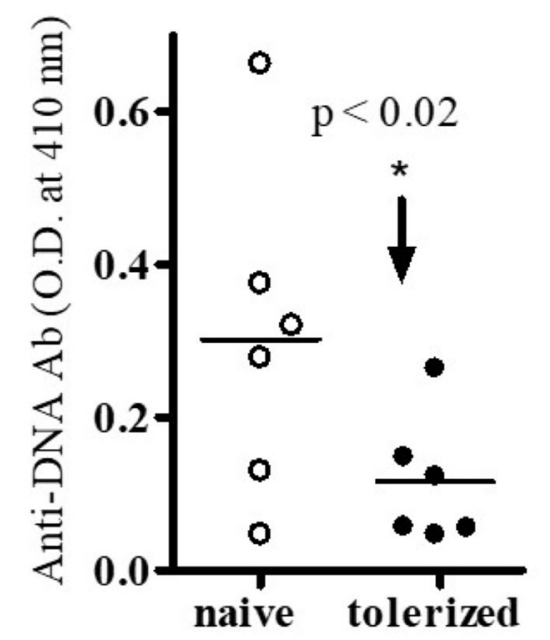

Tol granulocytes

FIGURE 2 | Anti-DNA Ab was significantly decreased in the presence of tolerized PMNs-granulocytes. Different immune cell subsets (naïve B cells, $1 \times 10^{5}$ cells from old nephritic mice; $\mathrm{CD} 4^{+} \mathrm{CD} 25^{-} \mathrm{T}$ cells, $1 \times 10^{6}$; naïv $\mathrm{CD} 8^{+} \mathrm{T}$ cells, $\left.1 \times 10^{5}\right)$ were isolated and cultured with tolerized granulocytes $\left(\mathrm{GR}, 1 \times 10^{6}\right)$. Cell subsets were isolated from total spleen cells of BWF1 mice. Cells were cultured in RPMl 1640 supplemented with L-glutamine (2 mM), penicillin (100 units/ml), streptomycin $(0.1 \mathrm{mg} / \mathrm{ml})$, 2-mercaptoethanol (Gibco) and $10 \%$ fetal bovine serum (FBS). After the 72- 96 hours range, culture supernatants were obtained. AntiDNA Ab levels were measured from culture supernatants by ELISA. ${ }^{*} p<0.05$. 
indicate that TNFAIP2 (Tumor necrosis factor alpha-induced protein 2) was increased $\sim 2$-fold (Figure 3A), and Ptdss2 (Phosphatidylserine synthase 2 and GATA1 (GATA-binding factor 1) $m R N A$ were upregulated more than 10-fold in tolerized granulocytes compared to naïve granulocytes (Figures 3B, C). In contrast, the mRNA of all the above genes (Figures 3D-F) and those of IFN-induced genes including IFI203 and IFI205 (Figures 3G, H) were down regulated in tolerized B cells. Although, the decreased level of IFI203 and IFI205 did not reach to the significance. However, other IFNs genes were significantly decreased. Thus, this data displays dynamic interplay and suggests that pCons has differential effects on different interferon genes in our tolerance model. Collectively these data demonstrate that pCons treatment modify the interferon's gene signature differentially in tolerized B cells and granulocytes.

\section{pCons-Tolerized B Cells From Lupus Mice Have Increased FoxP3 mRNA and Bcl2 Protein Levels}

The transcription factor forkhead box P3 (FoxP3), also known as scurfin, plays an important role in the maintenance of immunological homeostasis and restoration of self-tolerance. Dysfunction and mutations of the FoxP3 gene causes immunodysregulation polyendocrinopathy enteropathy X-linked (or IPEX) syndrome. FoxP3 also participates in maintaining the immune system response (38) and in the development and function of regulatory $\mathrm{T}$ cells (39-42). In the present study, we evaluated the expression of FoxP3 in pCons-tolerized B cells of lupus (BWF1 mice) compared with naïve B cells. Surprisingly, we found significantly increased expression of FoxP3 in tolerized B cells compared to naïve B cells (Figure 3I). Next, we investigated the protein expression of $b c l 2$ from cell lysates of tolerized B cells and naïve B cells with Western blot assay. We found that tolerized B cells have decreased levels of Bcl2 protein compared to naïve B cells (Figure 3J). Bcl-2 regulates cell death (apoptosis) by promoting or inhibiting apoptosis $(43,44)$. We have shown previously that $\mathrm{CD} 4^{+}$and $\mathrm{CD}^{+} \mathrm{T}$ cells from tolerized mice have significantly reduced apoptosis. Thus our data suggest that pCons tolerance may also affect apoptosis of B cells in our tolerance model and may play a significant role in survival of these cells by regulating immune tolerance.

\section{pCons Treatment Induced and Modified the Cell Surface Expression Markers for Regulatory B Cells}

Our previous study showed that pCons treatment induces both $\mathrm{CD}^{+}$and $\mathrm{CD}^{+}$regulatory $\mathrm{T}$ cells $(29,32,36)$. Based on these data and our gene expression study (33), we hypothesize that pCons treatment may induce suppressor/regulatory B cells $\left(B_{\text {regs }}\right)$ and granulocyte cells with the potential to suppress the proliferation of naïve $\mathrm{CD} 4^{+} \mathrm{CD} 25^{-}$cells and naïve $\mathrm{B}$ cells as well as the production of anti-DNA Ab. To address this, we isolated spleen cells from female BWF1 mice after one week of pCons treatment (1 mg i.v) and performed immunophenotyping studies with flow cytometry from naïve and pCons-treated mice (Figures 4A, F live gating scheme). We found that pCons treatment of BWF1 mice increases percent expression of
$\mathrm{CD}_{19}{ }^{+} \mathrm{CD} 1 \mathrm{~d}^{+}$regulatory B cells including median fluorescence intensity (Figures 4B, G, D, E). This is an important finding because two previous studies have revealed similar phenotype of $\mathrm{B}_{\text {regs }}$ in SLE patients $(45,46)$. Further, we found that pCons treatment reduces the percent expression of $\mathrm{CD} 19^{+} \mathrm{CD}^{+} \mathrm{B}$ cells (Figures 4C, H, I). The median fluorescence intensity (MFI) of $\mathrm{CD} 19^{+} \mathrm{CD}^{+}$cells were significantly decreased in pCons treated mice (Figure 4J). These data show that pCons treatment modified the B cells expression markers CD1d and CD5, and since we have also shown that $\mathrm{CD}^{+}$and $\mathrm{CD}^{+} \mathrm{T}$ cells from tolerized mice suppress autoreactive $\mathrm{B}$ cells and could account for their reduced numbers, this suggests that pCons treatment induces regulatory B cells.

\section{pCons Treatment Increased CD4 ${ }^{+}$FoxP3 $^{+}$ Regulatory T Cells and Significantly Reduced Percent Expression and Median Fluorescence Intensity of CTLA-4 (Cytotoxic T-Lymphocyte-Associated Proten-4) in CD8 ${ }^{+} \mathrm{T}$ Cells of BWF1 Lupus Mice}

We were interested to see whether pCons treatment induces regulatory $\mathrm{T}$ cells and whether it affects CTLA-4 expression. CTLA-4 plays an important role in immune tolerance and T-cell activation. We found that pCons treatment significantly increased the number of $\mathrm{CD}^{+}{ }^{+} \mathrm{FoxP}^{+} \mathrm{T}$ cells in BWF1 mice compared to naïve and/or saline-treated mice (Figures $\mathbf{5 A - D}$, F-H). We also measured the CTLA-4 expression on T cells $\left(\mathrm{CD}^{+} \mathrm{T}\right.$ cells) and found that percent expression of CTLA-4 was significantly decreased in pCons treated mice (Figure 5E) Further, we found that pCons treatment significantly reduced the median fluorescence intensity (MFI) of CTLA-4 expression in $\mathrm{CD}^{+} \mathrm{T}$ cells compared to naïve mice (Figures 5I, J). Thus, the data shows the immunomodulatory role of pCons in BWF1 mice. However, future study is warranted to pinpoint the exact mechanism of pCons activity in Lupus.

\section{DISCUSSION}

In the present study, we have added to previous work showing that pCons induces $\mathrm{CD} 8^{+}$and $\mathrm{CD} 4^{+}$suppressive cells and shown that $\mathrm{B}$ cells and granulocytes from tolerized mice suppress antiDNA Ab production in vitro. Several suppressive mechanisms/ factors may be involved including IL-10, TGF $\beta$, IL-35, and combinations of TLR9, CD40, and/or B cell receptor (BCR) and engagement of CD80/CD86 on $\mathrm{B}_{\text {regs }}(45,47)$. pCons treatment significantly increased the number of $\mathrm{CD} 4{ }^{+} \mathrm{FoxP} 3{ }^{+} \mathrm{T}$ cells. In earlier studies, we showed that these FoxP3 ${ }^{+} \mathrm{T}$ cells (both $\mathrm{CD}^{+}$and $\mathrm{CD}^{+} \mathrm{T}_{\text {reg) }}$ suppressed autoimmunity in vivo and antiDNA production in vitro $(29,32,36)$. Immune tolerance induced by pCons prolonged survival of BWF1 lupus mice (NZB/NZW) F1 and delayed the appearance of glomerulonephritis $(29,31$, 35). The pCons-induced regulatory $\mathrm{T}$ cells suppressed proliferation of naïve $\mathrm{CD} 4^{+} \mathrm{T}$ cells and naïve $\mathrm{CD} 19^{+} / \mathrm{B} 220^{+} \mathrm{B}$ cells and the production of anti-DNA antibodies (29, 32, 34-36). 

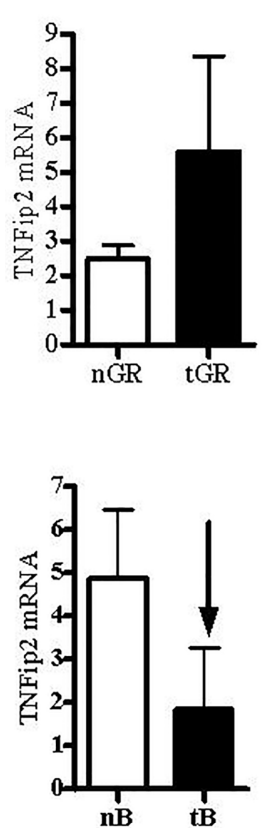

G

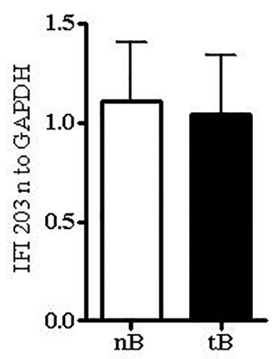

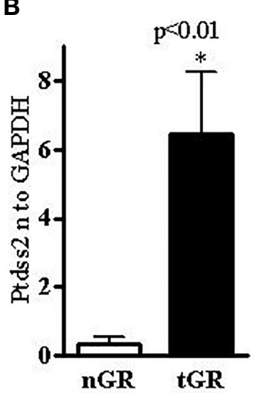

E

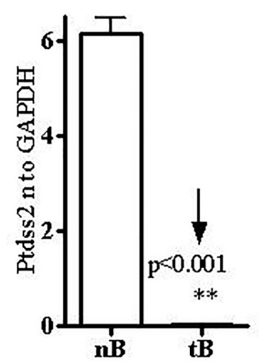

C

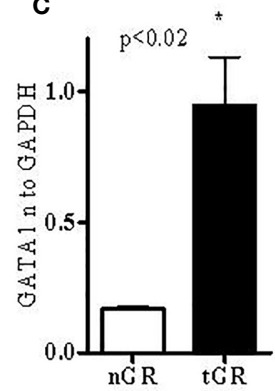

$\mathbf{F}$

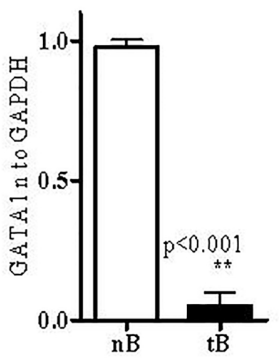

H
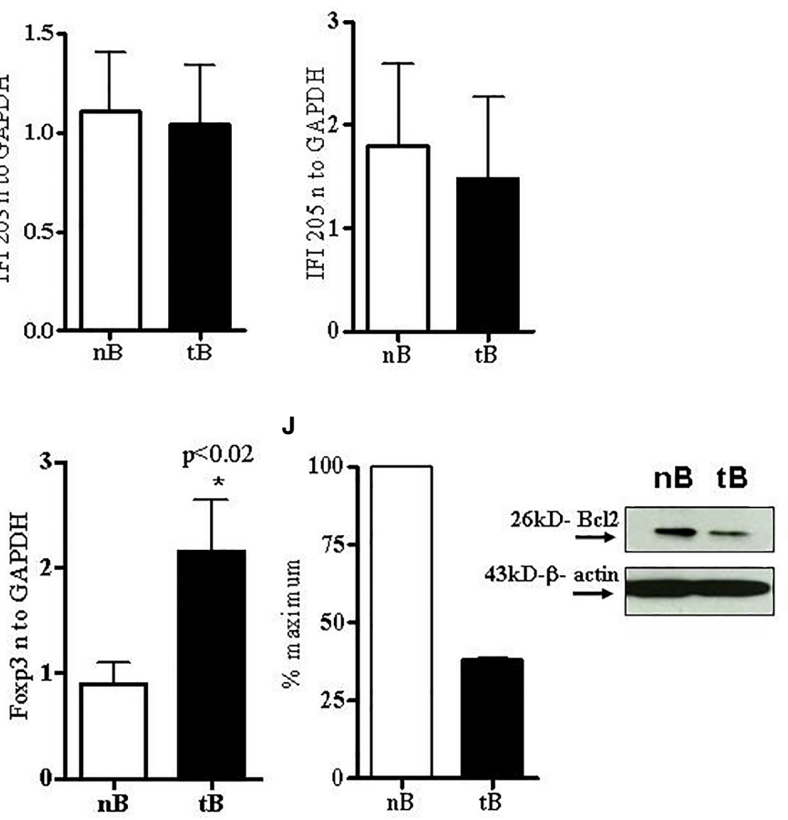

FIGURE 3 | Tolerized B cells have reduced IFNs gene mRNA and Bcl2 protein level and increased FoxP3 mRNA expression. RNA was isolated from naïve and tolerized B cells and granulocytes. Real time PCR was performed with $100 \mathrm{ng}$ of RNA with gene specific primers and probes. Data was normalized with GAPDH mRNA levels. ${ }^{*} \mathrm{p}<0.05$. TNFAIP2, Ptdss2, and GATA1 mRNA was increased (A-C) in tolerized granulocytes (GR) but reduced in tolerized B cells (D-F). IFI203 and IFI205 was decreased in tolerized B cells (G, H). (I) FoxP3 expression was increased in tolerized B cells. (J) Quantification of Western blot analysis of Bcl2 protein levels in cell lysates from naïve and tolerized sorted B (CD45R/B220) cells.

T cell suppressive capacity correlated with modulation of Mitogen-Activated Protein kinase (p38 MAP kinase) activity and FoxP3 expression in $\mathrm{CD}^{+}{ }^{+}$Tregs (48). In the current study we found that CTLA-4 median fluorescence intensity was significantly decreased in the $\mathrm{CD}^{+} \mathrm{T}$ cells of pCons-treated BWF1 mice. This is a significant finding as CTLA-4 is involved in negative signaling and plays a pivotal inhibitory role in $\mathrm{T}$ cell anergy and prevention of autoimmunity. In addition, recent 
A Naïve-WBC

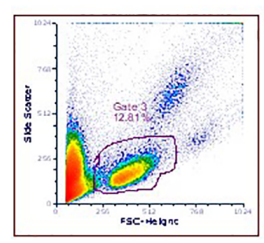

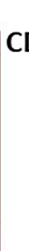

B

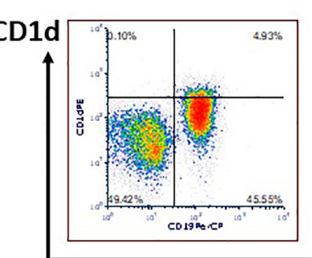

G

CD1d

pCons WBC
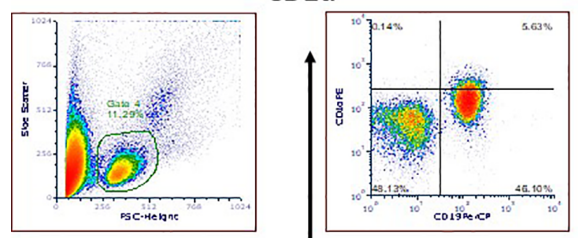

C

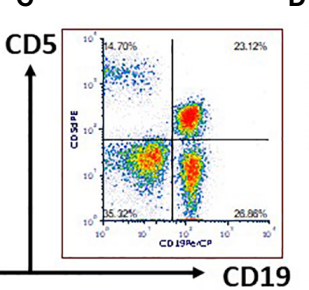

CD19

H

CD5

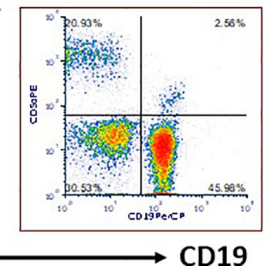

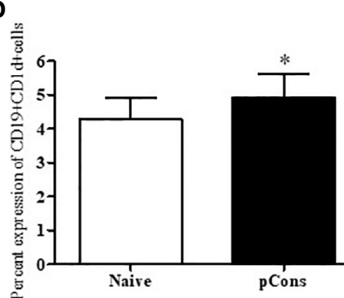

I

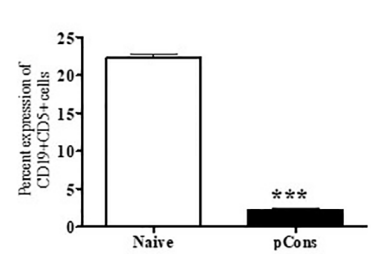

E
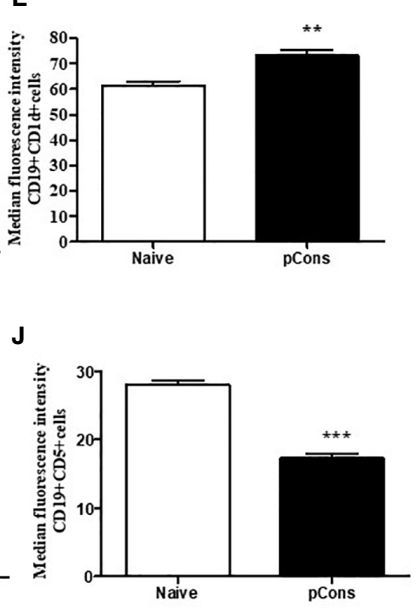

FIGURE 4 | pCons treatment modified the cell surface expression markers for regulatory B cells. Female 35-wk old BWF1 mice were treated with pCons (1 mg i.v.). After 3 days, blood was obtained, RBC lysed, and cells were stained with CD19, CD1d and CD5 antibodies and FACS performed. Representative live cell gating strategy (A, F) and FACS analysis of CD1d (B, G) and CD5 (C, H) expression levels from representative naïve (A-C) and pCons treated $(\mathbf{F}-\mathbf{H})$ mice. Percent expression of $\mathrm{CD}_{1} \mathrm{9}^{+} \mathrm{CD} 1 \mathrm{~d}^{+}$cells in naïve vs pCons treated mice (D). Percent expression of CD19 ${ }^{+} \mathrm{CD}^{+}$cells in naiive vs pCons treated mice (I). Quantification of Median Fluorescent Intensity of naïve and pCons-treated mice for CD1d (E) (from B and G Gate 3 and 4) and CD5 (J) (from C and H Gate 3 and 4). CD1d increased and CD5 cells decreased with pCons treatment. ${ }^{*} p<0.05,{ }^{* *} p<0.001,{ }^{\star * *} p<0.0001$.

A Naïve-Unstained CD25 Naive

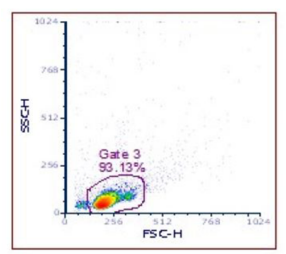

$\mathbf{F}$
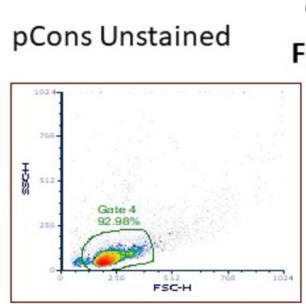

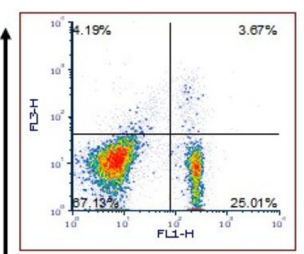

G Naive Foxp3

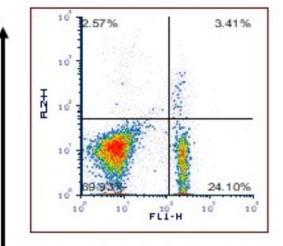
pCons
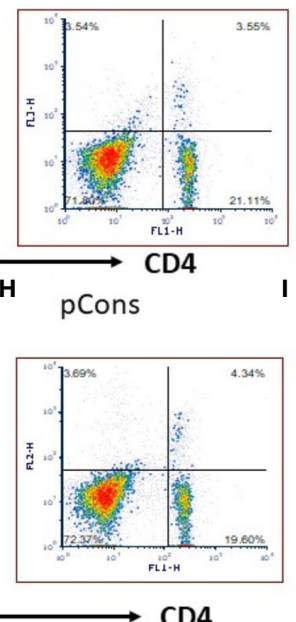
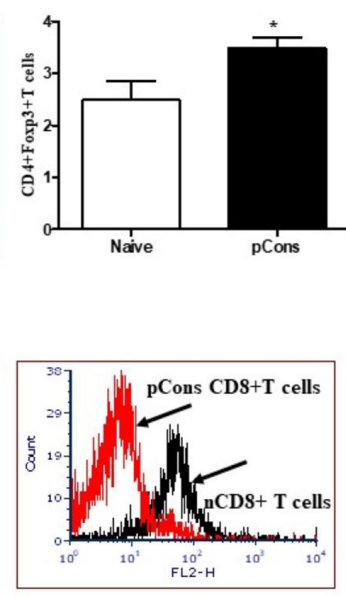

CTLA-4
E
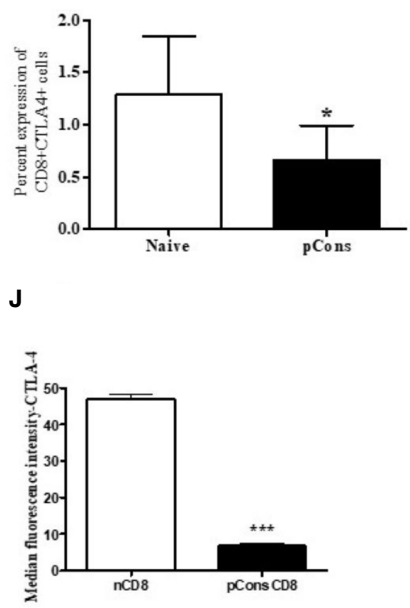

FIGURE 5 | pCons treatment increased CD4 ${ }^{+}$FoxP3 ${ }^{+}$regulatory T cells and significantly reduced Median Fluorescence Intensity of CTLA-4 (Cytotoxic T-lymphocyteAssociated Proten-4) in $\mathrm{CD}^{+} \mathrm{T}$ cells of BWF1 lupus mice. Female 12-20 wk-old BWF1 mice were treated with pCons (1mg i.v.). After 1-2 weeks, splenocytes were obtained, RBC lysed, and cells were stained with CD4, CD8, CD25, CTLA-4 and FoxP3 antibodies and FACS performed. 10,000 minimum cells were gated. Representative gating strategy $(\mathbf{A}, \mathbf{F})$ and FACS analyses of $\left.\mathrm{CD}^{+} \mathrm{CD} 25^{+} \mathbf{( B}, \mathbf{C}\right), \mathrm{CD}^{+} \mathrm{FoxP} 3^{+}(\mathbf{G}, \mathbf{H})$ and cumulative two-three experiments data for $\mathrm{CD} 4^{+} \mathrm{FoxP} 3^{+}$ cells (D) are shown. Cumulative data of $\mathrm{CD}^{+} \mathrm{CTLA}-4^{+} \mathrm{T}$ cells experiments (two-three) is shown (E). CTLA-4 staining (MFI) on CD8 ${ }^{+} \mathrm{T}$ cells is shown (I, $\left.\mathbf{J}\right)$. $\mathrm{CD}^{+}{ }^{+}$FoxP3 ${ }^{+} \mathrm{T}$ cells are significantly increased. CTLA-4 MFI is significantly decreased. ${ }^{*} \mathrm{p}<0.05,{ }^{* \star} \mathrm{p}<0.001,{ }^{\star \star \star} \mathrm{p}<0.0001$.

studies show that CTLA-4 controls follicular helper T cells and regulatory $\mathrm{T}$ cells, thereby controlling the $\mathrm{B}$ cells responses and humoral immunity (49-51). CTLA-4 also downregulates CD80 and CD86 on antigen presenting cells (APC); thus, altering the level of CD28 engagement on follicular helper T cells (51). However, its precise mechanism of action has not been fully 
resolved. Recently abnormal CTLA-4 gene polymorphisms and function has been reported in SLE patients $(52,53)$.

For the first time to our knowledge, in this system we found that B cells and granulocytes also can be "tolerized" and subsequently function as regulatory/suppressor cells to prevent production of autoantibodies. In the current experiments, we used whole tolerized $\mathrm{B}$ cells and granulocytes for the suppression assay. We acknowledge the next step is to test the specific $B_{\text {regs }}$ subsets to determine cell specificity and their mode of action and mechanism. Therefore, detailed molecular and cellular mechanisms of regulatory B cells and granulocytes are not completely clear and future study will be required to address this shortcoming.

Regulatory B cells and regulatory granulocytes are not well characterized in this SLE tolerance model and this study provided first novel mechanistic insight. We showed that 1) pCons tolerance altered expression of several candidate genes (see below) including interferon genes in tolerized B cells and granulocytes compared to naive cells; 2) pCons tolerance modified the cell surface expression of regulatory $\mathrm{B}$ cells (and/or deleted the $\mathrm{CD} 19^{+} \mathrm{CD} 5^{+}$subset); 3) pCons tolerance increased the percent expression of $\left(\mathrm{CD} 19^{+} \mathrm{CD} 1 \mathrm{~d}^{+}\right)$cells; and 4) pCons-tolerized B cells and granulocytes significantly reduced the production of anti-DNA antibody in cell culture experiments of lupus mouse cells.

pCons tolerance has been shown to affect various genes and markers, cell surface molecules, cytokines and different cell types including regulatory T cells (both CD4 and CD8) $(29-35,37)$. In the present study, we showed that pCons induced B cells enriched in markers identifying suppressor B cells and these cells have significantly reduced interferon-induced genes (IFN) such as, ptdss2, GATA1, and TNFip2 (Figure 3) compared to naïve mice. In contrast, we also found that these genes were significantly increased in tolerized granulocytes, with the exception of TNFip2 which was upregulated but did not reach the significance level (Figure 3) demonstrating differential effect of pCons. Thus, our data indicate dynamic interplay of these genes or their gene products in different immune cell subsets in our pCons-induced tolerance model. How this interplay affects the overall immune response in lupus mice is not clear. However, recent studies have shown the importance of interferon genes in lupus (54-58). Lupus is characterized by the dysregulation of both the innate and the adaptive immune systems. An increased expression of type I IFN-regulated genes, termed IFN signature, has been reported in the majority of patients with SLE (59-61). In agreement with our findings, another study found that a tolerogenic peptide of the light chain complementaritydetermining region 1 (hCDR1) down-regulates the expression of interferon-alpha (IFN- $\alpha$ ) in murine and human SLE (62). IFN- $\alpha$ plays a major role in SLE pathogenesis and the levels of IFN- $\alpha$ were increased and correlated with SLE disease activity in the sera of mice and humans (63-65). Administration of exogenous IFN- $\alpha$ leads to worsening of disease in various mouse models (66). Type 1 IFN contributes to loss of tolerance and increases production of autoantibodies (67), induces differentiation of monocytes to myeloid-derived dendritic cells (mDC) (56), and plays a vital role in the activation of autoreactive T and B cells (68). Activation of TLR7 and TLR9 is thought to be central to induction of the type 1 IFN response $(69,70)$. Indeed, a recent therapeutic option in patients with lupus is through inhibition of type IFN- $\alpha$ and several recent clinical trial data suggest therapeutic benefit (71-73). Thus, our findings that pCons tolerance reduces the IFN genes in our lupus model has direct clinical and translational significance.

We have shown earlier that pCons peptide delayed the onset of autoimmunity in lupus mouse model by inducing immune tolerance and up-regulating FoxP3 in $\mathrm{T}$ cells which are suppressive $(31,34,74)$. Other studies have reported that peptides from CDRs of pathogenic anti-DNA $\mathrm{Ab}$ could also prevent autoantibody production and down-regulate autoreactive $\mathrm{T}$ cell responses $(75,76)$. Similar to our results, these studies showed that a peptide derived from the CDR1 of a human anti-DNA Ab (hCDR1) could ameliorate lupus by inducing $\mathrm{T}_{\text {regs }}$ and suppressing the activation of autoreactive $\mathrm{T}$ cells through mechanisms including downregulation of transcription factors responsible for negative regulation of T-cell activation in lupus animal models (62, 76-79). Furthermore, clinical trial data has indicated safety and efficacy of hCDR1 (edratide) in SLE patients (80).

We demonstrated with flow cytometry (FACS) immunophenotyping that after pCons treatment the $\mathrm{CD} 19^{+} \mathrm{CD} 1 \mathrm{~d}^{+}$regulatory $\mathrm{B}$ cell subset was significantly increased in BWF1 lupus mice compared to naïve mice (Figures $\mathbf{4 B}, \mathbf{G}, \mathbf{D}$ ). However, the $\mathrm{CD} 19^{+} \mathrm{CD} 5^{+} \mathrm{B}$ cell subset was significantly decreased (Figures $\mathbf{4 C}, \mathbf{H}, \mathbf{I}$ ). This is a significant finding and the next step will be to decipher the mechanisms with future functional studies including testing B cells from anti-CD5 treated control mice. In agreement with our experiments, a previous study showed that anti-CD5 therapy decreases severity of established disease in collagen-induced arthritis in DBA/1 mice (81). Thus, our data with pCons therapy has clinical and therapeutic relevance in peptide induced immune tolerance. We also found that tolerized B cells have significant increased FoxP3 mRNA. Another study reported that the expansion of $\mathrm{CD} 25^{\text {thi }} \mathrm{CD}^{+}$and FoxP3 ${ }^{+}$regulatory B cells is associated with SLE disease activity in humans (82). Similarly, the presence of FoxP $^{+} \mathrm{CD} 19^{+} \mathrm{CD}^{+} \mathrm{B}$ cells in human peripheral blood mononuclear cells has also been reported (83). The diverse suppressive mechanisms of these regulatory B cells are through IL-10, TGF $\beta$, and IL-35. Previously we have demonstrated that pCons-induced splenocytes have significantly increased amount of TGF $\beta$, smad2, and smad3 expression and tolerized total $\mathrm{CD} 8^{+} \mathrm{T}$ cells have increased amount of IL-10 (37). Although, we did not measure the expression of IL-10, TGF $\beta$ and IL-35 in the regulatory $\mathrm{B}$ cells in our model, it is tempting to speculate that these molecules will play important role in our system based on our previous data. Thus, our findings may suggest that pCons tolerance promotes tolerized B cells that can suppress the autoimmune responses. Similar to our study, hCDR1 tolerance has effects on B cell activating factor (BAFF) and B-cell CD74 macrophage inhibitory factor in murine lupus $(84,85)$. The reduced levels of BAFF correlated with reduced rate of maturation and differentiation of $B$ cells and decrease in integrin expression. Recent studies provided further evidence of targeting of BAFF/BLys and APRIL in the management of lupus (86-88); and another study reported the effect of hCDR1 on IL-7 and apoptosis (89) and showed the rate of 
apoptosis is reduced with hCDR1 treatment in lupus mice. Bcl2 and $\mathrm{BCl}^{-\mathrm{XL}}$ levels were further reduced, and this was associated with reduced activation of $\mathrm{T}$ and $\mathrm{B}$ cells (90). We demonstrated earlier that pCons-induced $\mathrm{CD}^{+} \mathrm{T}_{\text {regs }}$ are resistant to apoptosis $(29,34)$. In the present study, we found that bcl 2 protein level was significantly decreased in tolerized $\mathrm{B}$ cells compared to naïve $\mathrm{B}$ cells thus affecting the survival of these cells in BWF1 mice. This is in agreement with another study that revealed increased expression of $\mathrm{Bcl} 2$ leads to development of SLE like symptoms in Bcl2 transgenic mice (91). Thus, altogether, our data suggests that pCons' effect on tolerized B cells and down-regulation of IFNs and bcl2 may play overall therapeutic beneficial effects in our tolerance model.

\section{DATA AVAILABILITY STATEMENT}

The raw data supporting the conclusions of this article will be made available by the authors, without undue reservation.

\section{ETHICS STATEMENT}

The animal study was reviewed and approved by UCLA Animal Research Committee (ARC).

\section{REFERENCES}

1. Kotzin BL. Systemic Lupus Erythematosus. Cell (1996) 85:303-6. doi: 10.1016/S0092-8674(00)81108-3

2. Wakeland EK, Liu K, Graham RR, Behrens TW. Delineating the Genetic Basis of Systemic Lupus Erythematosus. Immunity (2001) 15:397-408. doi: 10.1016/S1074-7613(01)00201-1

3. Theofilopoulos AN, Dixon FJ. Murine Models of Systemic Lupus Erythematosus. Adv Immunol (1985) 37:269-390. doi: 10.1016/S0065-2776(08)60342-9

4. Karim MR, Wang YF. Phenotypic Identification of CD19(+)CD5(+)CD1d(+) Regulatory B Cells That Produce Interleukin 10 and Transforming Growth Factor Betal in Human Peripheral Blood. Arch Med Sci (2019) 15:1176-83. doi: 10.5114/aoms.2018.77772

5. Li W, Tian X, Lu X, Peng Q, Shu X, Yang H, et al. Significant Decrease in Peripheral Regulatory B Cells is an Immunopathogenic Feature of Dermatomyositis. Sci Rep (2016) 6:27479. doi: 10.1038/srep27479

6. Mauri C, Menon M. Human Regulatory B Cells in Health and Disease: Therapeutic Potential. J Clin Invest (2017) 127:772-9. doi: 10.1172/JCI85113

7. Morris A, Moller G. Regulation of Cellular Antibody Synthesis Effect of Adoptively Transferred Antibody-Producing Spleen Cells on Cellular Antibody Synthesis. J Immunol (1968) 101:439-45.

8. L'Age-Stehr J, Teichmann H, Gershon RK, Cantor H. Stimulation of Regulatory T Cell Circuits by Immunoglobulin-Dependent Structures on Activated B Cells. Eur J Immunol (1980) 10:21-6. doi: 10.1002/eji.1830100105

9. Kennedy MW, Thomas DB. A Regulatory Role for the Memory B Cell as Suppressor-Inducer of Feedback Control. J Exp Med (1983) 157:547-58. doi: 10.1084/jem.157.2.547

10. Evans DE, Munks MW, Purkerson JM, Parker DC. Resting B Lymphocytes as APC for Naive T Lymphocytes: Dependence on CD40 Ligand/CD40. J Immunol (2000) 164:688-97. doi: 10.4049/jimmunol.164.2.688

11. Bouaziz JD, Yanaba K, Tedder TF. Regulatory B Cells as Inhibitors of Immune Responses and Inflammation. Immunol Rev (2008) 224:201-14. doi: 10.1111/ j.1600-065X.2008.00661.x

12. Lund FE. Cytokine-Producing B Lymphocytes-Key Regulators of Immunity. Curr Opin Immunol (2008) 20:332-8. doi: 10.1016/j.coi.2008.03.003

13. Mauri C, Ehrenstein MR. The 'Short' History of Regulatory B Cells. Trends Immunol (2008) 29:34-40. doi: 10.1016/j.it.2007.10.004

\section{AUTHOR CONTRIBUTIONS}

RPS contributed to the experimental design, obtaining funding, conducting experiments, analyzing data, preparing figures, and writing of the manuscript. BHH contributed to funding and editing of the manuscript. DSB contributed to figure and manuscript editing. All authors contributed to the article and approved the submitted version.

\section{FUNDING}

This work was supported by the NIH grants AR54034, AI 083894, AI65645 to RPS, UCLA Senate Core Grant to BHH and RPS, and UCLA Oppenheimer Clinical Seed Grant and American Autoimmune Related Disease Association grant to RPS.

\section{ACKNOWLEDGMENTS}

We thank the UCLA Flow Cytometry Core Facility for cell sorting and FACS experiments, Dr. Desmond Smith's Lab for the real time PCR, Dr. Ravi Dinesh for technical help, and Dr. Antonio La Cava for intellectual insights.

14. Mizoguchi A, Bhan AK. A Case for Regulatory B Cells. J Immunol (2006) 176:705-10. doi: 10.4049/jimmunol.176.2.705

15. Serra P, Santamaria P. To 'B' Regulated: B Cells as Members of the Regulatory Workforce. Trends Immunol (2006) 27:7-10. doi: 10.1016/j.it.2005.11.003

16. Yanaba K, Bouaziz JD, Haas KM, Poe JC, Fujimoto M, Tedder TF. A Regulatory B Cell Subset With a Unique CD1dhiCD5+ Phenotype Controls T Cell-Dependent Inflammatory Responses. Immunity (2008) 28:639-50. doi: 10.1016/j.immuni.2008.03.017

17. Yanaba K, Bouaziz JD, Matsushita T, Tsubata T, Tedder TF. The Development and Function of Regulatory B Cells Expressing IL-10 (B10 Cells) Requires Antigen Receptor Diversity and TLR Signals. J Immunol (2009) 182:7459-72. doi: 10.4049/jimmunol.0900270

18. Iking-Konert C, Ostendorf B, Sander O, Jost M, Wagner C, Joosten L, et al. Transdifferentiation of Polymorphonuclear Neutrophils to Dendritic-Like Cells at the Site of Inflammation in Rheumatoid Arthritis: Evidence for Activation by T Cells. Ann Rheum Dis (2005) 64:1436-42. doi: 10.1136/ard.2004.034132

19. Premchand P, Takeuchi K, Bjarnason I. Granulocyte, Macrophage, Monocyte Apheresis for Refractory Ulcerative Proctitis. Eur J Gastroenterol Hepatol (2004) 16:943-5. doi: 10.1097/00042737-200409000-00023

20. Suzuki Y, Yoshimura N, Saniabadi AR, Saito Y. Selective Granulocyte and Monocyte Adsorptive Apheresis as a First-Line Treatment for Steroid Naive Patients With Active Ulcerative Colitis: A Prospective Uncontrolled Study. Dig Dis Sci (2004) 49:565-71. doi: 10.1023/B:DDAS.00000 26299.43792.ae

21. Zehntner SP, Brickman C, Bourbonniere L, Remington L, Caruso M, Owens T. Neutrophils That Infiltrate the Central Nervous System Regulate T Cell Responses. J Immunol (2005) 174:5124-31. doi: 10.4049/jimmunol. 174.8.5124

22. Prior C, Townsend PJ, Hughes DA, Haslam PL. Induction of Lymphocyte Proliferation by Antigen-Pulsed Human Neutrophils. Clin Exp Immunol (1992) 87:485-92. doi: 10.1111/j.1365-2249.1992.tb03024.x

23. Potter NS, Harding CV. Neutrophils Process Exogenous Bacteria Via an Alternate Class I MHC Processing Pathway for Presentation of Peptides to T Lymphocytes. J Immunol (2001) 167:2538-46. doi: 10.4049/jimmunol.167.5.2538

24. Tvinnereim AR, Hamilton SE, Harty JT. Neutrophil Involvement in CrossPriming CD8+ T Cell Responses to Bacterial Antigens. J Immunol (2004) 173:1994-2002. doi: 10.4049/jimmunol.173.3.1994 
25. Beauvillain C, Delneste Y, Scotet M, Peres A, Gascan H, Guermonprez P, et al. Neutrophils Efficiently Cross-Prime Naive T Cells In Vivo. Blood (2007) 110:2965-73. doi: 10.1182/blood-2006-12-063826

26. Culshaw S, Millington OR, Brewer JM, McInnes IB. Murine Neutrophils Present Class II Restricted Antigen. Immunol Lett (2008) 118:49-54. doi: 10.1016/j.imlet.2008.02.008

27. Muller I, Munder M, Kropf P, Hansch GM. Polymorphonuclear Neutrophils and T Lymphocytes: Strange Bedfellows or Brothers in Arms? Trends Immunol (2009) 30:522-30. doi: 10.1016/j.it.2009.07.007

28. Gupta S, Kaplan MJ. The Role of Neutrophils and NETosis in Autoimmune and Renal Diseases. Nat Rev Nephrol (2016) 12:402-13. doi: 10.1038/nrneph.2016.71

29. Hahn BH, Singh RP, La Cava A, Ebling FM. Tolerogenic Treatment of Lupus Mice With Consensus Peptide Induces FoxP3-expressing, ApoptosisResistant, TGFbeta-secreting Cd8+ T Cell Suppressors. J Immunol (2005) 175:7728-37. doi: 10.4049/jimmunol.175.11.7728

30. Hahn BHA, La Cava A. The Anti-DNA Ig Consensus Peptide Pcons Facilitates Regulatory T Cell Activity in SLE Patients. Arthritis Rheum (2007) 56:S546-547.

31. Hahn BH, Singh RR, Wong WK, Tsao BP, Bulpitt K, Ebling FM. Treatment With a Consensus Peptide Based on Amino Acid Sequences in Autoantibodies Prevents T Cell Activation by Autoantigens and Delays Disease Onset in Murine Lupus. Arthritis Rheum (2001) 44:432-41. doi: 10.1002/1529-0131 (200102) 44:2<432::AID-ANR62>3.0.CO;2-S

32. La Cava A, Ebling FM, Hahn BH. Ig-Reactive CD4+CD25+ T Cells From Tolerized (New Zealand Black X New Zealand White)F1 Mice Suppress In Vitro Production of Antibodies to DNA. J Immunol (2004) 173:3542-8. doi: 10.4049/jimmunol.173.5.3542

33. Singh RP, Dinesh R, Elashoff D, de Vos S, Rooney RJ, Patel D, et al. Distinct Gene Signature Revealed in White Blood Cells, CD4(+) and CD8(+) T Cells in (Nzbx NZW) F1 Lupus Mice After Tolerization With Anti-DNA Ig Peptide. Genes Immun (2010) 11:294-309. doi: 10.1038/gene.2010.6

34. Singh RP, La Cava A, Hahn BH. Pconsensus Peptide Induces Tolerogenic Cd8+ T Cells in Lupus-Prone (NZB X NZW)F1 Mice by Differentially Regulating FoxP3 and PD1 Molecules. J Immunol (2008) 180:2069-80. doi: 10.4049/ jimmunol.180.4.2069

35. Singh RP, La Cava A, Wong M, Ebling F, Hahn BH. Cd8+ T Cell-Mediated Suppression of Autoimmunity in a Murine Lupus Model of Peptide-Induced Immune Tolerance Depends on FoxP3 Expression. J Immunol (2007) 178:7649-57. doi: 10.4049/jimmunol.178.12.7649

36. Hahn BH, Anderson M, Le E, La Cava A. Anti-Dna Ig Peptides Promote Treg Cell Activity in Systemic Lupus Erythematosus Patients. Arthritis Rheum (2008) 58:2488-97. doi: 10.1002/art.23609

37. Dinesh R, Hahn BH, La Cava A, Singh RP. Interferon-Inducible Gene 202b Controls CD8(+) T Cell-Mediated Suppression in Anti-DNA Ig PeptideTreated (NZB X NZW) F1 Lupus Mice. Genes Immun (2011) 12:360-9. doi: 10.1038/gene.2011.4

38. Brunkow ME, Jeffery EW, Hjerrild KA, Paeper B, Clark LB, Yasayko SA, et al. Disruption of a New Forkhead/Winged-Helix Protein, Scurfin, Results in the Fatal Lymphoproliferative Disorder of the Scurfy Mouse. Nat Genet (2001) 27:68-73. doi: $10.1038 / 83784$

39. Fontenot JD, Gavin MA, Rudensky AY. FoxP3 Programs the Development and Function of CD4+CD25+ Regulatory T Cells. Nat Immunol (2003) 4:3306. doi: $10.1038 /$ ni904

40. Fontenot JD, Rasmussen JP, Williams LM, Dooley JL, Farr AG, Rudensky AY. Regulatory T Cell Lineage Specification by the Forkhead Transcription Factor FoxP3. Immunity (2005) 22:329-41. doi: 10.1016/j.immuni.2005.01.016

41. Hori S, Nomura T, Sakaguchi S. Control of Regulatory T Cell Development by the Transcription Factor FoxP3. Science (2003) 299:1057-61. doi: 10.1126/ science. 1079490

42. Marson A, Kretschmer K, Frampton GM, Jacobsen ES, Polansky JK, MacIsaac KD, et al. FoxP3 Occupancy and Regulation of Key Target Genes During Tcell Stimulation. Nature (2007) 445:931-5. doi: 10.1038/nature05478

43. Tsujimoto Y, Finger LR, Yunis J, Nowell PC, Croce CM. Cloning of the Chromosome Breakpoint of Neoplastic B Cells With the T(14;18) Chromosome Translocation. Science (1984) 226:1097-9. doi: 10.1126/ science.6093263

44. Cleary ML, Smith SD, Sklar J. Cloning and Structural Analysis of cDNAs for Bcl-2 and a Hybrid bcl-2/immunoglobulin Transcript Resulting From the T
(14;18) Translocation. Cell (1986) 47:19-28. doi: 10.1016/0092-8674(86) 90362-4

45. Blair PA, Norena LY, Flores-Borja F, Rawlings DJ, Isenberg DA, Ehrenstein MR, et al. CD19(+)CD24(Hi)CD38(Hi) B Cells Exhibit Regulatory Capacity in Healthy Individuals But are Functionally Impaired in Systemic Lupus Erythematosus Patients. Immunity (2010) 32:129-40. doi: 10.1016/ j.immuni.2009.11.009

46. Yang X, Yang J, Chu Y, Xue Y, Xuan D, Zheng S, et al. T Follicular Helper Cells and Regulatory B Cells Dynamics in Systemic Lupus Erythematosus. PloS One (2014) 9:e88441. doi: 10.1371/journal.pone.0088441

47. Flores-Borja F, Bosma A, Ng D, Reddy V, Ehrenstein MR, Isenberg DA, et al. Cd19+Cd24hicd38hi B Cells Maintain Regulatory T Cells While Limiting TH1 and TH17 Differentiation. Sci Trans Med (2013) 5:173ra23. doi: 10.1126/ scitranslmed. 3005407

48. Lourenco EV, Procaccini C, Ferrera F, Iikuni N, Singh RP, Filaci G, et al. Modulation of P38 MAPK Activity in Regulatory T Cells After Tolerance With Anti-DNA Ig Peptide in (NZB X NZW)F1 Lupus Mice. J Immunol (2009) 182:7415-21. doi: 10.4049/jimmunol.0804214

49. Sage PT, Paterson AM, Lovitch SB, Sharpe AH. The Coinhibitory Receptor CTLA-4 Controls B Cell Responses by Modulating T Follicular Helper, T Follicular Regulatory, and T Regulatory Cells. Immunity (2014) 41:1026-39. doi: 10.1016/j.immuni.2014.12.005

50. Wing K, Onishi Y, Prieto-Martin P, Yamaguchi T, Miyara M, Fehervari Z, et al. CTLA-4 Control Over FoxP3+ Regulatory T Cell Function. Science (2008) 322:271-5. doi: 10.1126/science.1160062

51. Wang CJ, Heuts F, Ovcinnikovs V, Wardzinski L, Bowers C, Schmidt EM, et al. CTLA-4 Controls Follicular Helper T-cell Differentiation by Regulating the Strength of CD28 Engagement. Proc Natl Acad Sci USA (2015) 112:524-9. doi: 10.1073/pnas.1414576112

52. Jury EC, Flores-Borja F, Kalsi HS, Lazarus M, Isenberg DA, Mauri C, et al. Abnormal CTLA-4 Function in T Cells From Patients With Systemic Lupus Erythematosus. Eur J Immunol (2010) 40:569-78. doi: 10.1002/eji.200939781

53. Liu J, Zhang HX. CTLA-4 Polymorphisms and Systemic Lupus Erythematosus: A Comprehensive Meta-Analysis. Genet Test Mol Biomarkers (2013) 17:226-31. doi: 10.1089/gtmb.2012.0302

54. Choubey D, Panchanathan R. Interferon-Inducible Ifi200-family Genes in Systemic Lupus Erythematosus. Immunol Lett (2008) 119:32-41. doi: 10.1016/ j.imlet.2008.06.001

55. Crow MK. Type I Interferon in the Pathogenesis of Lupus. J Immunol (2014) 192:5459-68. doi: 10.4049/jimmunol.1002795

56. Ronnblom L, Pascual V. The Innate Immune System in SLE: Type I Interferons and Dendritic Cells. Lupus (2008) 17:394-9. doi: 10.1177/ 0961203308090020

57. Luo S, Wang Y, Zhao M, Lu Q. The Important Roles of Type I Interferon and Interferon-Inducible Genes in Systemic Lupus Erythematosus. Int Immunopharmacol (2016) 40:542-9. doi: 10.1016/j.intimp.2016.10.012

58. Bezalel S, Guri KM, Elbirt D, Asher I, Sthoeger ZM. Type I Interferon Signature in Systemic Lupus Erythematosus. Isr Med Assoc J (2014) 16:246-9.

59. Crow MK. Type I Interferon in Systemic Lupus Erythematosus. Curr Top Microbiol Immunol (2007) 316:359-86. doi: 10.1007/978-3-540-71329-6_17

60. Crow MK. Type I Interferon in Organ-Targeted Autoimmune and Inflammatory Diseases. Arthritis Res Ther (2010) 12(Suppl 1):S5. doi: 10.1186/ar2886

61. Crow MK. Advances in Understanding the Role of Type I Interferons in Systemic Lupus Erythematosus. Curr Opin Rheumatol (2014) 26:467-74. doi: 10.1097/BOR.0000000000000087

62. Sthoeger Z, Zinger H, Sharabi A, Asher I, Mozes E. The Tolerogenic Peptide, hCDR1, Down-Regulates the Expression of Interferon-Alpha in Murine and Human Systemic Lupus Erythematosus. PloS One (2013) 8:e60394. doi: 10.1371/journal.pone.0060394

63. Baechler EC, Batliwalla FM, Karypis G, Gaffney PM, Ortmann WA, Espe KJ, et al. Interferon-Inducible Gene Expression Signature in Peripheral Blood Cells of Patients With Severe Lupus. Proc Natl Acad Sci USA (2003) 100:26105. doi: $10.1073 /$ pnas. 0337679100

64. Crow MK, Kirou KA. Interferon-Alpha in Systemic Lupus Erythematosus. Curr Opin Rheumatol (2004) 16:541-7. doi: 10.1097/01.bor.0000135453.70424.1b

65. Ytterberg SR, Schnitzer TJ. Serum Interferon Levels in Patients With Systemic Lupus Erythematosus. Arthritis Rheum (1982) 25:401-6. doi: 10.1002/ art.1780250407 
66. Liu Z, Davidson A. Ifnalpha Inducible Models of Murine Sle. Front Immunol (2013) 4:306. doi: 10.3389/fimmu.2013.00306

67. Domeier PP, Chodisetti SB, Schell SL, Kawasawa YI, Fasnacht MJ, Soni C, et al. B-Cell-Intrinsic Type 1 Interferon Signaling Is Crucial for Loss of Tolerance and the Development of Autoreactive B Cells. Cell Rep (2018) 24:406-18. doi: 10.1016/j.celrep.2018.06.046

68. Kiefer K, Oropallo MA, Cancro MP, Marshak-Rothstein A. Role of Type I Interferons in the Activation of Autoreactive B Cells. Immunol Cell Biol (2012) 90:498-504. doi: 10.1038/icb.2012.10

69. Celhar T, Fairhurst AM. Toll-Like Receptors in Systemic Lupus Erythematosus: Potential for Personalized Treatment. Front Pharmacol (2014) 5:265. doi: 10.3389/fphar.2014.00265

70. Fillatreau S, Manfroi B, Dorner T. Toll-Like Receptor Signalling in B Cells During Systemic Lupus Erythematosus. Nature Reviews. Rheumatology (2020) 17, 98-108. doi: 10.1038/s41584-020-00544-4

71. Khamashta M, Merrill JT, Werth VP, Furie R, Kalunian K, Illei GG, et al. Sifalimumab, an Anti-Interferon-Alpha Monoclonal Antibody, in Moderate to Severe Systemic Lupus Erythematosus: A Randomised, Double-Blind, Placebo-Controlled Study. Ann Rheum Dis (2016) 75:1909-16. doi: 10.1136/ annrheumdis-2015-208562

72. Kalunian KC, Merrill JT, Maciuca R, McBride JM, Townsend MJ, Wei X, et al. A Phase II Study of the Efficacy and Safety of Rontalizumab (rhuMAb Interferon-Alpha) in Patients With Systemic Lupus Erythematosus (ROSE). Ann Rheum Dis (2016) 75:196-202. doi: 10.1136/annrheumdis-2014-206090

73. Chaichian Y, Wallace DJ, Weisman MH. A Promising Approach to Targeting Type 1 IFN in Systemic Lupus Erythematosus. J Clin Invest (2019) 129:95861. doi: 10.1172/JCI127101

74. Singh RR, Ebling FM, Sercarz EE, Hahn BH. Immune Tolerance to Autoantibody-Derived Peptides Delays Development of Autoimmunity in Murine Lupus. J Clin Invest (1995) 96:2990-6. doi: 10.1172/JCI118371

75. Waisman A, Ruiz PJ, Israeli E, Eilat E, Konen-Waisman S, Zinger H, et al. Modulation of Murine Systemic Lupus Erythematosus With Peptides Based on Complementarity Determining Regions of a Pathogenic anti-DNA Monoclonal Antibody. Proc Natl Acad Sci USA (1997) 94:4620-5. doi: 10.1073/pnas.94.9.4620

76. Sthoeger ZM, Dayan M, Tcherniack A, Green L, Toledo S, Segal R, et al. Modulation of Autoreactive Responses of Peripheral Blood Lymphocytes of Patients With Systemic Lupus Erythematosus by Peptides Based on Human and Murine anti-DNA Autoantibodies. Clin Exp Immunol (2003) 131:385-92. doi: 10.1046/j.1365-2249.2003.02058.x

77. Sharabi A, Haviv A, Zinger H, Dayan M, Mozes E. Amelioration of Murine Lupus by a Peptide, Based on the Complementarity Determining Region-1 of an Autoantibody as Compared to Dexamethasone: Different Effects on Cytokines and Apoptosis. Clin Immunol (2006) 119:146-55. doi: 10.1016/j.clim.2006.01.007

78. Sharabi A, Zinger H, Zborowsky M, Sthoeger ZM, Mozes E. A Peptide Based on the Complementarity-Determining Region 1 of an Autoantibody Ameliorates Lupus by Up-Regulating CD4+CD25+ Cells and TGF-Beta. Proc Natl Acad Sci USA (2006) 103:8810-5. doi: 10.1073/pnas.0603201103

79. Sela U, Mauermann N, Hershkoviz R, Zinger H, Dayan M, Cahalon L, et al. The Inhibition of Autoreactive T Cell Functions by a Peptide Based on the CDR1 of an anti-DNA Autoantibody is Via TGF-beta-mediated Suppression of LFA-1 and CD44 Expression and Function. J Immunol (2005) 175:7255-63. doi: $10.4049 /$ jimmunol.175.11.7255

80. Urowitz MB, Isenberg DA, Wallace DJ. Safety and Efficacy of hCDR1 (Edratide) in Patients With Active Systemic Lupus Erythematosus: Results of Phase II Study. Lupus Sci Med (2015) 2:e000104. doi: 10.1136/lupus-2015-000104
81. Plater-Zyberk C, Taylor PC, Blaylock MG, Maini RN. Anti-CD5 Therapy Decreases Severity of Established Disease in Collagen Type II-induced Arthritis in DBA/1 Mice. Clin Exp Immunol (1994) 98:442-7. doi: 10.1111/ j.1365-2249.1994.tb05510.x

82. Vadasz Z, Peri R, Eiza N, Slobodin G, Balbir-Gurman A, Toubi E. The Expansion of CD25 High IL-10 High FoxP3 High B Regulatory Cells is in Association With SLE Disease Activity. J Immunol Res (2015) 2015:254245. doi: $10.1155 / 2015 / 254245$

83. Noh J, Choi WS, Noh G, Lee JH. Presence of FoxP3-expressing Cd19(+)Cd5 $(+)$ B Cells in Human Peripheral Blood Mononuclear Cells: Human CD19(+) CD5(+)FoxP3(+) Regulatory B Cell (Breg). Immune Netw (2010) 10:247-9. doi: $10.4110 /$ in.2010.10.6.247

84. Parameswaran R, Ben David H, Sharabi A, Zinger H, Mozes E. B-Cell Activating Factor (BAFF) Plays a Role in the Mechanism of Action of a Tolerogenic Peptide That Ameliorates Lupus. Clin Immunol (2009) 131:22332. doi: 10.1016/j.clim.2008.12.009

85. Lapter S, Ben-David H, Sharabi A, Zinger H, Telerman A, Gordin M, et al. A Role for the B-cell CD74/Macrophage Migration Inhibitory Factor Pathway in the Immunomodulation of Systemic Lupus Erythematosus by a Therapeutic Tolerogenic Peptide. Immunology (2011) 132:87-95. doi: 10.1111/j.13652567.2010.03342.x

86. La Cava A. Targeting the BLyS-APRIL Signaling Pathway in SLE. Clin Immunol (2013) 148:322-7. doi: 10.1016/j.clim.2012.11.010

87. Stohl W. Therapeutic Targeting of the BAFF/APRIL Axis in Systemic Lupus Erythematosus. Expert Opin Ther Targets (2014) 18:473-89. doi: 10.1517/ 14728222.2014 .888415

88. Stohl W. Inhibition of B Cell Activating Factor (BAFF) in the Management of Systemic Lupus Erythematosus (SLE). Expert Rev Clin Immunol (2017) 13:623-33. doi: 10.1080/1744666X.2017.1291343

89. Ben-David H, Sharabi A, Parameswaran R, Zinger H, Mozes E. A Tolerogenic Peptide Down-Regulates Mature B Cells in Bone Marrow of Lupus-Afflicted Mice by Inhibition of interleukin-7, Leading to Apoptosis. Immunology (2009) 128:245-52. doi: 10.1111/j.1365-2567.2009.03109.x

90. Sharabi A, Luger D, Ben-David H, Dayan M, Zinger H, Mozes E. The Role of Apoptosis in the Ameliorating Effects of a CDR1-based Peptide on Lupus Manifestations in a Mouse Model. J Immunol (2007) 179:4979-87. doi: 10.4049/jimmunol.179.8.4979

91. Strasser A, Whittingham S, Vaux DL, Bath ML, Adams JM, Cory S, et al. Enforced BCL2 Expression in B-lymphoid Cells Prolongs Antibody Responses and Elicits Autoimmune Disease. Proc Natl Acad Sci USA (1991) 88:8661-5. doi: $10.1073 /$ pnas.88.19.8661

Conflict of Interest: BHH and RPS have a patent through the University of California, Los Angeles for the use of pCons as an immune modulator in systemic lupus erythematosus.

The remaining author declares that the research was conducted in the absence of any commercial or financial relationships that could be construed as a potential conflict of interest.

Copyright (c) 2021 Singh, Hahn and Bischoff. This is an open-access article distributed under the terms of the Creative Commons Attribution License (CC BY). The use, distribution or reproduction in other forums is permitted, provided the original author(s) and the copyright owner $(s)$ are credited and that the original publication in this journal is cited, in accordance with accepted academic practice. No use, distribution or reproduction is permitted which does not comply with these terms. 